\title{
Biological aspects of Leucothyreus ambrosius Blanchard (Coleoptera, Melolonthidae, Rutelinae)
}

\author{
Elias Soares Gomes ${ }^{1}$, Sérgio Roberto Rodrigues ${ }^{2} \&$ Miguel Angel Morón ${ }^{3}$
}

\author{
'Programa de Pós-Graduação em Entomologia e Conservação da Biodiversidade, Universidade Federal da Grande Dourados, Caixa Postal 241, \\ 79804-970 Dourados-MS, Brasil. eliasjv_gomes@hotmail.com \\ ${ }^{2}$ Universidade Estadual de Mato Grosso do Sul, Rodovia MS 306, km 6,4, 79540-000 Cassilândia-MS, Brasil. sergio@uems.br \\ ${ }^{3}$ Red de Biodiversidad y Sistemática, Instituto de Ecología, A. C. Apdo. Postal 63, Xalapa, Veracruz, 91000, México. \\ moronrios.miguelangel@gmail.com
}

\begin{abstract}
Biological aspects of Leucothyreus ambrosius Blanchard (Coleoptera, Melolonthidae, Rutelinae). Coleopterans of the family Melolonthidae comprise a large group of species that feed on different food sources, including plant roots, stems, and leaves, in addition to plant materials at different decomposition stages. Several species are found in the genus Leucothyreus, occurring in different regions of Brazil, including the various biomes in the country. Information on the biology of species of the genus Leucothyreus is scarce, therefore, we conducted studies on the biological aspects of Leucothyreus ambrosius Blanchard, 1850. The period of adult occurrence was determined with a light trap installed between a cropped and pasture area in the municipality of Aquidauana, Mato Grosso do Sul State, Brazil. Adults collected in the field were used to form insect pairs and the studies were initiated in the entomology laboratory as the adults began ovipositing. Adults were observed flying in the field from October to December. Eggs were obtained as pairs were formed and a colony was established, the embryonic period lasting 14.6 days on average. The larval period in the $1^{\text {st }}$ instar lasted 21.6 days, in the $2^{\text {nd }}$ instar 19.6 days, and in the $3^{\text {rd }}$ instar, 85.6 days. The head capsule width was $1.48 \mathrm{~mm}$ in the $1^{\text {st }}$ instar, $2.44 \mathrm{~mm}$ in the $2^{\text {nd }}$, and $3.83 \mathrm{~mm}$ in $3^{\text {rd }}$ larval instar. The pupal stage had an average duration of 35.5 days. The egg to adult period lasted 173.3 days. Morphometric information for the larval and adult stages is presented in this study.
\end{abstract}

KEYWORDS. Geniatini; Insecta; rizophagous insect; Scarabaeoidea; white grub.

The genus Leucothyreus MacLeay comprises 164 species occurring in several countries (Jameson 2008). The larval stages of species of Leucothyreus feed on plant roots, damaging them. Puker et al. (2009) found larvae of $L$. dorsalis Blanchard, 1850 and Leucothyreus sp. in the root systems of Acrocomia aculeata (Jacq.) Lodd. ex Mart (Arecaceae) in the state of Mato Grosso do Sul, Brazil. Pereira et al. (2013) sampled larvae of L. alvarengai Frey, 1976 and $L$. aff. semipruinosus Ohaus, 1917 developed in succession of soybean and corn systems in Tangará da Serra, Mato Grosso State, Brazil. In Colombia, larvae of L. femoratus Burmeister, 1844 and other species of this genus are listed as major pests of crops and pastures (Pardo-Locarno et al. 2003, 2005, 2006). In Chiapas, Mexico, species of Leucothyreus are considered important pests in agricultural areas because, according to Ramírez-Salinas \& Castro-Ramírez (2000), the larvae cause damage to roots of corn plants.

Adults of Leucothyreus may also be associated with different plant species. While studying Scarabaeidae species in the state of Minas Gerais, Brazil, Oliveira et al. (2001) recorded the occurrence of 14 species of Leucothyreus in a plantation of Eucalyptus grandis Hill ex Maiden. Puker et al. (2011) studied adult individuals of Leucothyreus albopilosus Ohaus, 1917, in the central-western region of Brazil. The adults were found in trunk lesions of Eucalyptus citriodora Hook and in hives of Africanized bees, Apis mellifera Linnaeus, 1758 (Hymenoptera, Apidae), where the adults remained in propolis layers. In Colombia, adults of L. femoratus feed on leaves of Elaeis guineensis Jacquin and daily consumption reaches 13 $\mathrm{mm}^{2} /$ insect (Martínez et al. 2013), causing severe defoliation.

Some information on the biological characteristics of the species of Leucothyreus is available. Rodrigues et al. (2010a) studied biological aspects of $L$. dorsalis occurring in the central-western region of Brazil, and observed that the egg to adult period is completed in 273.5 days. According to Pereira et al. (2013), adults of $L$. alvarengai and $L$. aff. semipruinosus are found in the field at the beginning of the rainy season, and during this period, the reproductive period begins and the larval stages are completed in less than a year. In Colombia, the egg-to-adult period of L. femoratus lasts 170.4 days (Martínez \& Plata-Rueda 2013).

The objective of this study was to investigate on the biological aspects of Leucothyreus ambrosius Blanchard, 1850 in the municipality of Aquidauana, Mato Grosso do Sul, Brazil. According to Morón (2004), in Brazil, 83 species of Leucothyreus have been reported and the occurrence of $L$. ambrosius has been observed only in the state of Mato Grosso, Brazil. 


\section{MATERIAL AND METHODS}

The studies were conducted at Universidade Estadual de Mato Grosso do Sul (UEMS), in the municipality of Aquidauana, Mato Grosso do Sul State, Brazil. To collect $L$. ambrosius adults, a light trap model "Luiz de Queiroz" equipped with a fluorescent light bulb (20 watts) was installed between pastures and cropped areas, from January 2010 to December 2011. The light bulb in the trap was turned on every day at 6 p.m. and off at 6 a.m. the next day.

The adults of $L$. ambrosius collected were kept in $4 \mathrm{~L}$ plastic tray $(20 \times 30 \times 12 \mathrm{~cm})$, with a $5 \mathrm{~cm}$ layer of soil and seedlings of Brachiaria decumbens Stapf. Each tray was identified and covered with voile fabric to prevent the insects from escaping (Rodrigues et al. 2008a). Two insect pairs were kept per tray for copulation and oviposition. The trays were inspected daily to observe the presence of eggs.

After oviposition, the eggs were transferred to Petri dishes containing moist soil and the dishes were kept in an incubator at $26 \pm 1^{\circ} \mathrm{C}$ and photophase of $12 \mathrm{~h}$. The material was inspected at intervals of 3-4 days to monitor embryonic development and the emergence of larvae (Rodrigues et al. 2010a).

After hatching, the larvae were separated in plastic jars (500 $\mathrm{mL}$ ) containing soil and seedlings of $B$. decumbens. The soil was moistened weekly and the seedlings were replaced by fresh ones every 15 days to supply roots for the larvae to feed on.

As the pre-pupae started to appear, seedlings of $B$. decumbens were no longer supplied. Observations were made on the egg to adult period. The pupae were kept under the same conditions as the pre-pupae.

The head capsule measurements were obtained for the larvae $(n=20)$ at the largest widths, similar to procedures of Rodrigues et al. (2008a) during their study on the biological aspects of Anomala testaceipennis Blanchard, 1856.

Adults of L. ambrosius were sexed, and some of them were measured, killed and kept in a drying oven for 48 hours $\left(60 \pm 5^{\circ} \mathrm{C}\right)$ to be weighed. The biological variables evaluated included the duration of the embryonic, larval, and pupal periods, and adult longevity.

The adults were identified by the third author by means of comparisons with material identified and deposited at the Zoologische Museum der Humboldt Universität zu Berlin, Germany, and with original descriptions by Blanchard (1851) and Ohaus $(1917,1918,1924,1931)$.

Twenty adults of L. ambrosius were deposited in the collection of the Entomology Laboratory, Universidade Estadual de Mato Grosso do Sul, in the municipality of Aquidauana, Mato Grosso do Sul, Brazil, and eight adults were deposited in the Colección Entomológica, Instituto de Ecología, A.C. Xalapa, Veracruz, Mexico (IEXA).

\section{RESULTS}

From January to September 2010, no adults of $L$. ambrosius were collected with the light trap. However, eight adults were collected in October, three in November, and five in December. In 2011, similarly to 2010, no adults were collected in the field from January to September. Twenty-two adults were collected in October and seven in November. The flight period of adults in both years occurred during the rainy season. Thus, the occurrence of adults in the field refers to the period from October to December (Fig. 1).

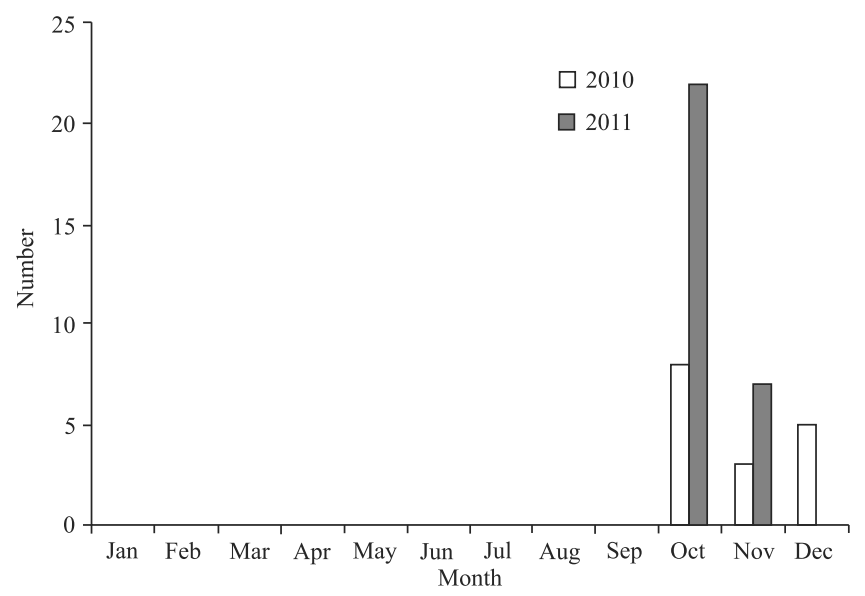

Fig. 1. Number of adults of Leucothyreus ambrosius Blanchard, 1850 collected in light traps from January 2010 to January 2011 in Aquidauana, Mato Grosso do Sul State, Brazil.

Eggs of L. ambrosius were laid during the months of October and November in the rearing trays in the laboratory (Fig. 2). The eggs were white, placed individually in chambers made in the soil, internally measuring $2.5 \mathrm{~mm}$ (length) by $2.1 \mathrm{~mm}$ (width) $(\mathrm{n}=25)$. Freshly laid eggs were oval, measuring $2.0 \mathrm{~mm}$ in length and $1.9 \mathrm{~mm}$ wide on average. As the embryonic development progressed, the eggs reached $2.4 \mathrm{~mm}$ in length and $2.0 \mathrm{~mm}$ wide on average $(\mathrm{n}=36)$. The embryonic period lasted 14.6 days on average (Table I).

Table I. Duration (mean $\pm \mathrm{SE}^{1}$ ) of the developmental stages of Leucothyreus ambrosius Blanchard, 1850 under laboratory conditions $\left(26 \pm 1^{\circ} \mathrm{C}\right.$, photoperiod of $12 \mathrm{~h})$

\begin{tabular}{lcccc}
\hline \multicolumn{1}{c}{ Stage } & Duration (days) & Interval (days) & $\mathrm{N}$ & Variability (\%) \\
\hline Egg & $14.6 \pm 0.9^{1}$ & $13-16$ & 37 & 83.78 \\
$1^{\text {st }}$ instar & $21.6 \pm 3.2$ & $18-28$ & 29 & 93.54 \\
$2^{\text {nd }}$ instar & $19.6 \pm 0.9$ & $18-21$ & 23 & 79.31 \\
$3^{\text {rd }}$ instar & $85,6 \pm 3,2$ & $81-90$ & 23 & 100.0 \\
Larval duration & $123.0 \pm 1.8$ & $121-127$ & 21 & 91.3 \\
Pupae & $35.5 \pm 5.5$ & $30-41$ & 21 & 100.0 \\
Egg to adult & $173.3 \pm 2.4$ & $170-178$ & 20 & 95.2 \\
\hline
\end{tabular}

${ }^{1} \mathrm{SE}=$ Standard error of the mean.

The duration of the $1^{\text {st }}$ instar of the larval stage was 21.6 days on average. The larval stage was observed in the rearing trays in October and November (Table I; Fig. 2). Newly hatched larvae measured $5.3 \mathrm{~mm}$ in length and $1.2 \mathrm{~mm}$ wide at thorax, on average, and they were slightly grey (Table II). The head capsule width was $1.48 \mathrm{~mm}$, on average. 


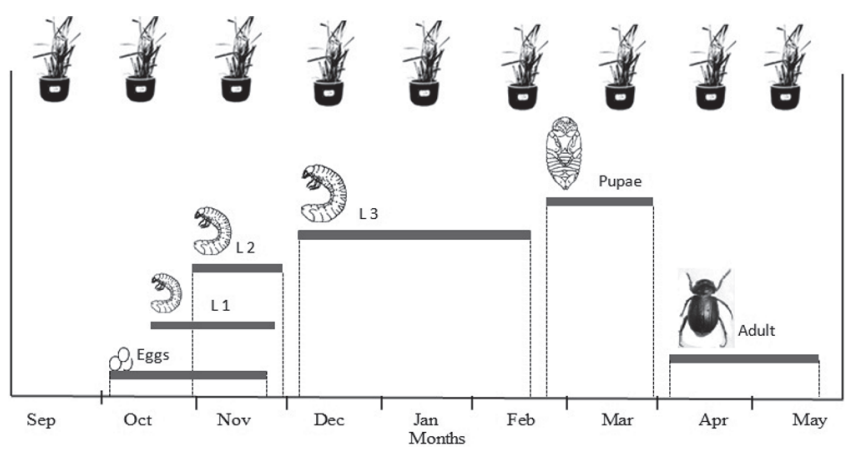

Fig. 2. Development of immature stages (eggs, larvae, pupae) and adults of Leucothyreus ambrosius in trays with seedlings of Brachiaria decumbens, reared in the laboratory $\left(26 \pm 1^{\circ} \mathrm{C}\right.$, photoperiod of $\left.12 \mathrm{~h}\right)$. ( $\mathrm{L} 1=$ first-instar larvae, L2 = second-instar larvae, and L3 = third-instar larvae).

The duration of the $2^{\text {nd }}$ instar of the larval stage was 19.6 days, occurring in November (Table I; Fig. 2). The head capsule width in the $2^{\text {nd }}$ instar was $2.44 \mathrm{~mm}$ and the larvae measured $16.6 \mathrm{~mm}$ in length and $3.8 \mathrm{~mm}$ wide at thorax on average (Table II).

The larvae remained in the $3^{\text {rd }}$ instar for 85.6 days on average, occurring from early December to late February (Table I; Fig. 2). The head capsule width was $3.83 \mathrm{~mm}$ and the average larval length was $22.1 \mathrm{~mm}$, with an average of $4.5 \mathrm{~mm}$ wide at thorax. The entire larval period lasted 123.0 days, on average (Table I).

At the end of $3^{\text {rd }}$ instar, the larvae made a pupal chamber at the bottom of the rearing tray, measuring $2.1 \times 1.5 \mathrm{~cm}$ internally and $3.5 \times 2.1 \mathrm{~cm}$ externally $(\mathrm{n}=6)$. The chambers probably consisted of soil and saliva, and the pupae remained in the chamber without feeding until they reached the adult stage. The pupal chamber served as shelter for the larvae, since the chamber structure hardly collapsed when handled in the laboratory. This microenvironment provides appropriate conditions for development.

Regarding the larval weight of $L$. ambrosius, larvae in the $1^{\text {st }}$ instar weighed $4.4 \mathrm{mg}$, in the $2^{\text {nd }}$ instar $162.0 \mathrm{mg}$, and in the $3^{\text {rd }}$ instar $324.0 \mathrm{mg}$ (Table II). The larvae increased their weights 73.6 times from the $1^{\text {st }}$ to the $3^{\text {rd }}$ instar.

In January, larvae in the $3^{\text {rd }}$ instar started to signal that they were reaching the pre-pupal stage as their activities decreased, feeding stopped (Fig. 2), and the color changed gradually going from grey to white.
Pupae of L. ambrosius were observed from late February through late March (Fig. 2). In the laboratory, the pupal stage had an average duration of 35.5 days (Table I). The pupae measured $18.0 \mathrm{~mm}$ in length and $7.4 \mathrm{~mm}$ wide at thorax, with an average weight of $342.0 \mathrm{mg}$ (Table II). Typically, the pupae were dark yellow on their dorsal region and light yellow on the ventral region. The adults started to emerge under laboratory conditions in early April and were observed until late May (Fig. 2).

Regarding adult size, females were on average $13.2 \mathrm{~mm}$ in length and $7.0 \mathrm{~mm}$ wide and they were larger than males, which measured $12.3 \mathrm{~mm}$ in length and $6.2 \mathrm{~mm}$ wide. Adult females were also heavier than adult males, weighing 56.9 $\mathrm{mg}$ and $35.7 \mathrm{mg}$, respectively (Table II).

Adults of L. ambrosius can be sexed based on the tarsomers of the first pair of legs, which in males are wider, thus male individuals can be easily identified (Fig. 3). The duration of the egg to adult period of L. ambrosius is 173.3 days (Table I; Fig. 2).
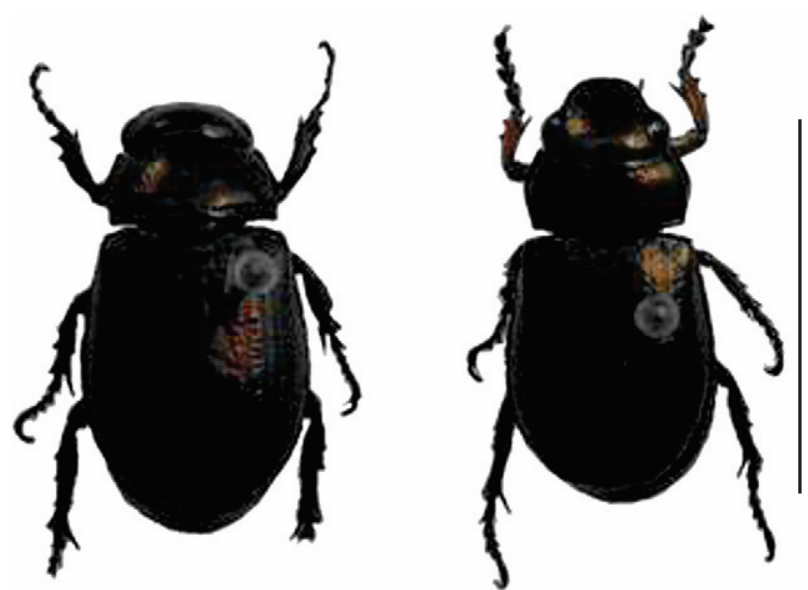

Fig. 3. Adults of Leucothyreus ambrosius: female (left) and male (right). Scale $=1 \mathrm{~cm}$.

\section{DISCUSSION}

Adults of L. ambrosius in Aquidauana, MS, occurred during the rainy season. According to Rodrigues et al. (2010a), swarms of $L$. dorsalis apparently start to occur in the field during the first rains. Thus, in September 2006, after an accu-

Table II. Average values $\left( \pm \mathrm{SE}^{1}\right)$ for length, width, and weight of the developmental stages of L. ambrosius Blanchard, 1850 in the laboratory $\left(26 \pm 1^{\circ} \mathrm{C}\right.$, photoperiod of $\left.12 \mathrm{~h}\right)$.

\begin{tabular}{|c|c|c|c|c|c|c|}
\hline \multirow{2}{*}{ Stage } & \multicolumn{2}{|c|}{ Length (mm) } & \multicolumn{2}{|c|}{ Width (mm) } & \multicolumn{2}{|c|}{ Weight (mg) } \\
\hline & Mean $\pm \mathrm{SE}$ & Interval & Mean $\pm \mathrm{SE}$ & Interval & Mean $\pm \mathrm{SE}$ & Interval \\
\hline Egg & $2.0 \pm 0.07$ & $1.9-2.1$ & $1.9 \pm 0.27$ & $1.80-2.35$ & - & - \\
\hline $1^{\text {st }}$ instar & $5.3 \pm 0.24$ & $4.4-6.1$ & $1.2 \pm 0.02$ & $1.12-1.3$ & $4.4 \pm 0.0$ & $3.9-5.1$ \\
\hline $2^{\text {nd }}$ instar & $16.6 \pm 0.77$ & $13.8-18.4$ & $3.8 \pm 0.13$ & $3.47-4.19$ & $162.0 \pm 0.01$ & $137.4-191.0$ \\
\hline $3^{\text {rd }}$ instar & $22.1 \pm 1.16$ & $14.2-29.6$ & $4.5 \pm 0.10$ & $3.82-5.1$ & $324.0 \pm 0.03$ & $161.8-525.0$ \\
\hline Pupa & $18.0 \pm 0.28$ & $17.5-18.5$ & $7.40 \pm 0.20$ & $7.0-7.7$ & $342.0 \pm 0.01$ & $34.0-344.0$ \\
\hline Adult $O^{n}$ & $12.3 \pm 0.12$ & $12.0-12.6$ & $6.2 \pm 0.13$ & $5.98-6.61$ & $35.7 \pm 0.02$ & $29.8-40.6$ \\
\hline Adult $O$ & $13.2 \pm 0.15$ & $12.9-13.5$ & $7.0 \pm 0.23$ & $6.8-7.52$ & $56.9 \pm 0.04$ & $47.1-63.3$ \\
\hline
\end{tabular}

${ }^{1} \mathrm{SE}=$ Standard error of the mean. 
mulated rainfall of $51.6 \mathrm{~mm}$, adults began to be collected. In the following year, adults were first collected in October 2007 , after an accumulated rainfall of $56.2 \mathrm{~mm}$. According to Pereira et al. (2013), at the beginning of the reproductive period of $L$. alvarengai and $L$. aff. semipruinosus, adults began to fly and soon after they started ovipositing in the field in September. Possibly, the beginning of the rainy season in the central-western region of Brazil may indicate the beginning of the flight period of adults of Leucothyreus.

Possibly, the occurrence of adults of L. ambrosius and their reproductive cycle are well adapted to the hot and humid climate conditions in the region of Aquidauana, MS, where the studies were carried out. Adults were captured with a light trap, thus, the insects swarmed at night. Adults of $L$. dorsalis were collected from 7 p.m. to 5:30 a.m. (Rodrigues et al. 2010a). Pardo-Locarno et al. (2006) stated that $L$. femoratus adults have crepuscular habits.

Eggs of L. ambrosius are larger than those of L. dorsalis (1.8 $\mathrm{mm}$ in length and $1.5 \mathrm{~mm}$ wide) (Rodrigues et al. 2010a), however, the embryonic periods in both species are similar. The embryonic period of $L$. femoratus is 8.73 days (Martínez \& Plata-Rueda 2013), therefore, shorter than that of $L$. ambrosius.

The behavior of adults of L. ambrosius laying eggs in chambers built in the soil has also been observed in other species of Melolonthidae, such as Liogenys fusca Blanchard, 1850, L. dorsalis, and Cyclocephala verticalis Burmeister, 1847 (Rodrigues et al. 2008b, 2010a, b). The chamber made for egg laying can be used as shelter to hatch larvae.

The head capsule widths of larvae of $L$. ambrosius were $1.48 \mathrm{~mm}, 2.44 \mathrm{~mm}$, and $3.83 \mathrm{~mm}$ for the $1^{\text {st }}, 2^{\text {nd }}$, and $3^{\text {rd }}$ instars, respectively. In L. dorsalis, the head capsule widths for the $1^{\text {st }}, 2^{\text {nd }}$, and $3^{\text {rd }}$ larval instars were $1.0,1.8$, and $2.8 \mathrm{~mm}$, respectively (Rodrigues et al. 2010a). Thus, larvae of $L$. ambrosius are larger than L. dorsalis and L. femoratus because, according to Pardo-Locarno et al. (2006), larvae in the $3^{\text {rd }}$ instar have maximum head capsule widths ranging from 3.0 to $3.2 \mathrm{~mm}$.

The larvae of the $3^{\text {rd }}$ instar of $L$. ambrosius, which are about to pupate, built a chamber in the soil where they remain sheltered. This behavior has been observed in several species of Melolonthidae, such as L. femoratus (Martínez \& Plata-Rueda 2013), Anomala testaceipennis Blanchard, 1850 and L. fuscus (Rodrigues et al. 2008ab), C. verticalis (Rodrigues et al. 2010b), and P. fulva (Rodrigues \& Falco 2011). Pupae of L. ambrosius are larger than those of $L$. femoratus, which are light yellow and measure about 14-16 $\mathrm{mm}$ in length and 7-12 mm wide (Pardo-Locarno et al. 2006).

The egg to adult period in L. ambrosius is completed in 173.3 days, in L. femoratus in 170.4 days (Martínez \& PlataRueda 2013), and much shorter than L. dorsalis, which lasts 273.5 days, according to Rodrigues et al. (2010a). In $L$. alvarengai and $L$. aff. semipruinosus, the egg to adult period is completed in less than a year (Pereira et al. 2013).

There are no previous records on the occurrence of $L$. ambrosius for the Mato Grosso do Sul State, Brazil. There- fore, in addition to the knowledge about its biological and morphometric aspects, this species is recorded in this State for the first time.

\section{ACKNOWLEDGMENTS}

The authors wish to thank the National Council for Scientific and Technological Development (CNPq) and the Foundation for Supporting the Development of Teaching, Science and Technology of the state of Mato Grosso do Sul (FUNDECT) for the financial support. We also give thanks to Joaquim Willers, from the Zoologische Museum der Humboldt Universität zu Berlin, for reference photographs used in the identification of the studied material.

\section{REFERENCES}

Blanchard, C.E. 1851. Catalogue de la Collection Entomologique. Classe des Insectes. Ordre des Coléoptères. v.1, part 2. Paris, Gide and Baudry.

Jameson, M.L. 2008. Review of the genus Microchilus Blanchard (Coleoptera: Scarabaeidae: Rutelinae: Geniatini). Insecta Mundi 25: 1-14.

Martínez, L.C. \& Plata-Rueda, A. 2013. Some biological aspects of Leucothyreus femoratus (Burmeister) (Coleoptera, Scarabaeidae), in oil palm plantations from Colombia. Journal of Entomological and Acarological Research 45: 27-32.

Martínez, L.C., Plata-Rueda, A., Zanuncio, J.C. \& Serrão, J.E. 2013. Leucothyreus femoratus (Coleoptera: Scarabaeidae): Feeding and behavioral activities as an oil palm defoliator. Florida Entomologist 96: $55-63$.

Morón, M.A. 2004. Melolonthídeos edafícolas, p. 133-166. In: Salvadori, J.R.; Ávila C.J. \& Silva, M.T.B. (eds.), Pragas de solo no Brasil. Passo Fundo: Embrapa Trigo; Dourados: Embrapa Agropecuária Oeste; Cruz Alta: Fundacep Fecotrigo, xi+541 p.

Oliveira, H.G., Zanuncio, T.V., Zanuncio, J.C. \& Santos, G.P. 2001. Coleópteros associados à eucaliptocultura na região de Nova Era, Minas Gerais, Brasil. Floresta e Ambiente 8: 52-60.

Ohaus, F. 1917. Neue Geniatinen (Col. Lamell. Rutelin.). Stettiner Entomologische Zeitung 78: 3-53.

Ohaus, F. 1918. Neue Geniatinen II (Col. Lamell. Rutelin.). Stettiner Entomologische Zeitung 79: 350-365.

Ohaus, F. 1924. Neue Geniatinen III (Col. Lamell. Rutelin.). Stettiner Entomologische Zeitung 84: 179-186.

Ohaus, F. 1931. Neue Geniatinen IV (Col.). Stettiner Entomologische Zeitung 92: 227-259.

Parco-Locarno, L.C., Montoya-Lerma, J. \& Schoonhoven, A.V. 2003. Abundancia de chisas rizófagas (Coleoptera: Melolonthidae) en agroecossistemas de Caldono y Buenos Aires, Cauca, Colombia. Revista Colombiana de Entomología 29: 177-183.

Pardo-Locarno, L.C., Montoya-Lerma, J., Bellotti, A.C. \& Schoonhoven, A.V. 2005. Structure and composition of the White Grub complex (Coleoptera: Scarabaeidae) in agroecological systems of northern Cauca, Colombia. Florida Entomologist 88: 355-363.

Pardo-Locarno, L.C., Morón, M.A. \& Montoya-Lerma, J. 2006. Descripción de los estados inmaduros de Leucothyreus femoratus Burmeister (Coleoptera: Melolonthidae: Rutelinae: Geniatini) con notas sobre su biología e importancia agrícola en Colombia. Folia Entomológica Mexicana 45: 179-193.

Pereira, A.F., Rodrigues, S.R. \& Morón, M.A. 2013. Biological aspects of Leucothyreus alvarengai Frey and Leucothyreus aff. semipruinosus Ohaus (Coleoptera, Melolonthidae, Rutelinae) in crop succession at central Brazil. Revista Brasileira de Entomologia 57: 323-328.

Puker, A., Morón, M.A., Oliveira Junior, O. \& Message, D. 2011. First 
record of Leucothyreus albopilosus (Coleoptera: Scarabaeidae: Rutelinae: Geniatini) in lesions on stem of Eucalytus citriodora and beehives of Apis mellifera. Entomological Science 14: 230-233.

Puker, A., Rodrigues, S.R., Tiago, E.F. \& Santos, W.T. 2009. Espécies de Scarabaeidae fitófagos (Insecta: Coleoptera) associadas ao sistema radicular de Acrocomia aculeata (Jacq.) Lodd. ex Mart. (Arecaceae). Biota Neotropica 9: 105-109.

Ramírez-Salinas, C. \& Castro-Ramírez, A.E. 2000. El complejo "gallina ciega" (Coleoptera: Melolonthidae) en el cultivo de maíz, en El Madronal, municipio de Amatenango Del Valle, Chiapas, México. Acta Zoologica Mexicana 79: 17-41.

Rodrigues, S.R., Puker, A., Abot, A.R., Barbosa, C.L., Ide, S. \& Coutinho, G.V. 2008a. Ocorrência e aspectos biológicos de Anomala testaceipennis Blanchard (Coleoptera, Scarabaeidae). Revista Brasileira de
Entomologia 52: 68-71.

Rodrigues, S.R., Barbosa, C.L., Puker, A., Abot, A.R. \& Ide, S. 2008b. Occurrence, biology and behavior of Liogenys fuscus Blanchard (Insecta, Coleoptera, Scarabaeidae) in Aquidauana, Mato Grosso do Sul, Brazil. Revista Brasileira de Entomologia 52: 637-640.

Rodrigues, S.R., Puker, A. \& Tiago, E.F. 2010a. Aspectos biológicos de Leucothyreus dorsalis Blanchard (Coleoptera, Scarabaeidae, Rutelinae). Revista Brasileira de Entomologia 54: 431-435.

Rodrigues, S.R., Nogueira, G.A.L., Echeverria, R.R. \& Oliveira, V.S. 2010b. Aspectos biológicos de Cyclocephala verticalis Burmeister (Coleooptera: Scarabaeidae). Neotropical Entomology 39: 15-18.

Rodrigues, S.R. \& Falco, J.S. 2011. Aspectos biológicos de Pelidnota fulva Blanchard, 1850 (Coleoptera, Scarabaeidae, Rutelinae). Biota Neotropica 11: $157-160$.

Received 25 November 2013; accepted 26 May 2014

Associate Editor: Lucia M. Almeida 